\title{
Analysis of Inequality of Economic Development in Districts/Cities Region of Kedu in Central Java Province
}

\author{
By: \\ Hisyam Maskanudin ${ }^{11}$, Arif Andri Wibowo ${ }^{2)}$ \\ ${ }^{1)}$ Dinas Perdagangan Kabupaten Wonosobo Provinsi Jawa Tengah \\ ${ }^{2)}$ Faculty of Economics and Business, Universitas Jenderal Soedirman \\ ${ }^{1)}$ Email: h1smas@yahoo.co.id
}

\begin{abstract}
Differences in the level of building economics between regions will result in imbalances that affect various regions that can have an adverse influence (backwash effect) beneficial effects (spreading effects) on regional growth. One indicator that is entirely representative to measure the level of development inequality between regions is the Williamson index. Inequality in the former Kedu residency during 2007-2016 continued to increase. This study aims to determine the factors that influence inequality in the former Kedu residency in that period. Independent variables include private investment, labor force, and Special Allocation Funds (DAK) in 6 regencies/cities of the former Kedu residency in 2007-2016. By using regression data panel analysis method, the results of the study show that private investment and DAK do not affect the imbalance of economic development.
\end{abstract}

Keywords: Regional Inequality, Private Investment, DAK, Labor Force, Williamson Index.

\begin{abstract}
ABSTRAK
Perbedaan tingkat kemajuan ekonomi antar wilayah akan menimbulkan ketidakseimbangan yang menjadikan terjadinya perbedaan antar wilayah yang dapatmemberikan pengaruh yang merugikan (backwash effects) mendominasi pengaruh yang menguntungkan (spread effects) terhadap pertumbuhan daerah. Salah satu indikator yang cukup representatif untuk mengukur tingkat ketimpangan pembangunan antar wilayah adalah indeks Williamson. Angka ketimpangan di eks karisidenan Kedu selama tahun 2007-2016 terus meningkat. Penelitian ini bertujuan unntuk menganalisis faktor-faktor yang mempengaruhi ketimpangan di eks karesidenan Kedu pada periode tersebut. Variabel independen yang digunakan meliputi investasi swasta, angkatan kerja, dan Dana Alokasi Khusus (DAK) di 6 kabupaten/kota eks karesidenan Kedu tahun 20072016. Dengan menggunakan metode analisis regresi data panel, hasil penelitian menunjukkan bahwa investasi swasta dan DAK tidak berpengaruh terhadap ketimpangan pembangunan ekonomi; serta Angkatan kerja berpengaruh positif terhadap ketimpangan pembangunan ekonomi.
\end{abstract}

Kata kunci: Ketimpangan Wilayah, Invetasi Swasta, DAK, Angkatan Kerja, Indeks Williamson.

\section{INTRODUCTION}

Local governments in Indonesia as policymakers have an important role in allocating resources as input for regional development, especially after the enactment of Law Number 32 of 2004 concerning Regional Autonomy. Regional development policies are left to each regional government, with different orientations (Li \& Wei, 2010). Some regions are oriented to economic growth as a development strategy, while some other areas are oriented towards improving the quality of human 
development. The diversity of resources, capabilities, needs, and potential in each region affect the implementation of development carried out by local governments (Lesmann, 2012).

The difference in the level of economic progress between regions that is excessive will cause adverse effects (backwash effects) to dominate the beneficial effects (spread effects) on regional growth, resulting in imbalances. Actors who have standard market power will tend to increase rather than decrease so that it will lead to increased inequality between regions (Lessmann, 2014).

One indicator that is quite representative to measure the level of development inequality between regions is the Williamson index. Although this index has several weaknesses, including sensitivity to the definition of the area used in the calculation, but the Williamson index is commonly used to measure the inequality of development between regions (Lessmann, 2014) Inequality in economic development in Central Java Province when measured through the Williamson index can be seen in the following figure.

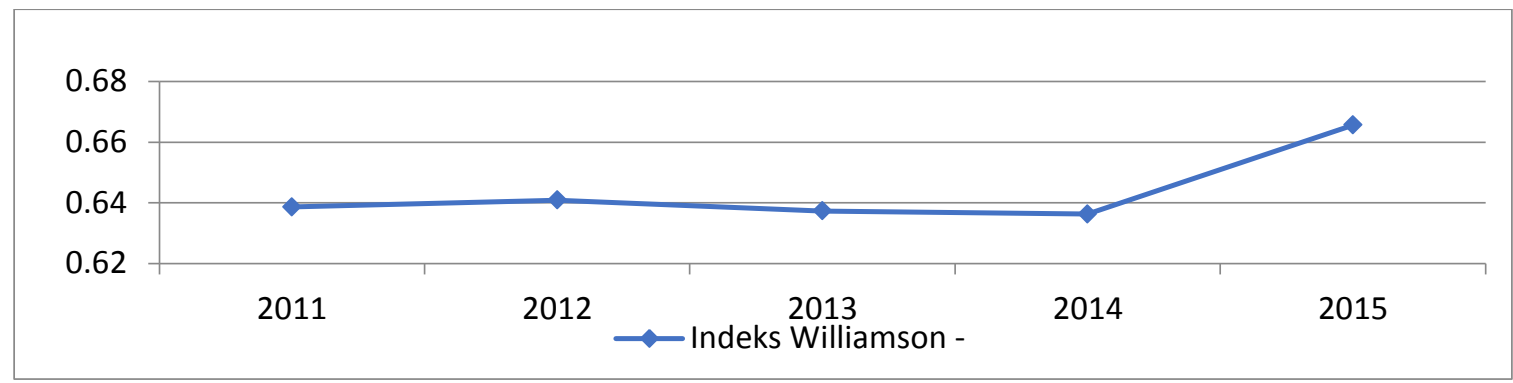

Figure 2. The Williamson Index of Central Java Province in 2011-2015

Source: Central Java Province January 2017 Macro Socio-Economic Indicator

From Figure 2 shows that the Williamson Index of Central Java Province from 2011-2015 is relatively stagnant at a high level of inequality because it is close to 1 (Sjafrizal, 2012), even inequality had increased sharply in 2015. Inequality of economic development also occurred in the ex Kedu Residency in Central Java Province, which includes Purworejo Regency, Kebumen Regency, Wonosobo Regency, Magelang Regency, and Temanggung Regency. This can be seen from the per capita income in the five districts in 2015 , namely as presented in the following table:

Table 1. Perkapita Revenue in 2016 Ex-Residency District of Kedu

\begin{tabular}{clc}
\hline No. & Dirtrict & Income per Capita (Rupiah) \\
\hline 1 & Purworejo District & $1.593 .000,00$ \\
2 & Kebumen District & $3.306 .000,00$ \\
3 & Wonosobo District & $1.611 .000,00$ \\
4 & Magelang District & $3.613 .000,00$ \\
5 & Temanggung District & $2.571 .000,00$ \\
\hline \multicolumn{2}{c}{ Source: Central Java in Figures, 2016}
\end{tabular}

\section{LITERATURE REVIEW}

\section{Development Inequality}

Development inequality is a reflection of the development gap regarding the economy from one region to another in Indonesia. The development of each region will be different depending on the potential and available sources of income and management so that it can lead to development imbalances (Nurhuda, Muluk, \& Prasetyo, 2013). Economic development inequality in this study was measured using the Williamson Index, which was calculated based on the ratio of population and GRDP per capita by constant prices in 2000 for districts/cities in the district/city of the former Kedu and Central Java provinces from 2007 to 2016. 


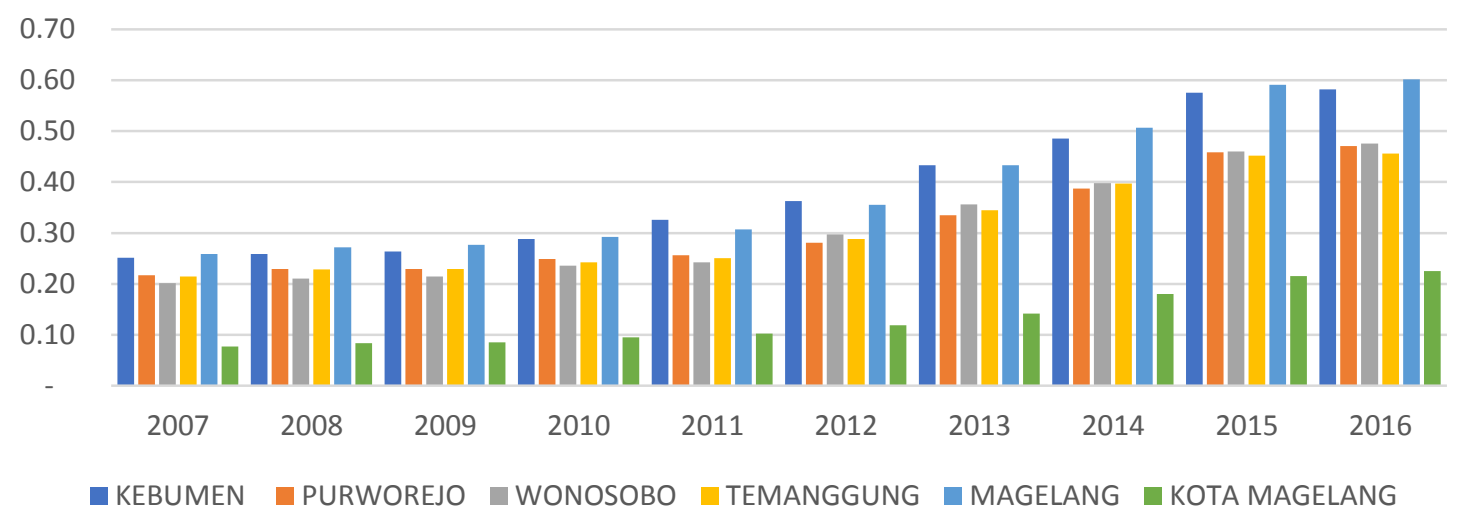

Figure 2. Inequality of Development in 6 Regencies/Cities in Ex-Kedu Residency 2007-2016 Source: Central Java in Figures 2008-2017, Processed

Capital stock or investment is an essential factor in determining economic growth and economic development. With the existence of new investments, there will be additional output and net income in the production factor, so that it will stimulate the rapid economic development activities that ultimately trigger economic growth (Ebong, Ogwumike, Udongwo, \& Ayodele, 2016). Investment is the expenditure or shopping of investors or companies to buy capital goods and production equipment to increase the ability to produce goods and services available in the economy so that investment is also called investment. Investment activities carried out by the community will continuously increase economic activities and employment opportunities, increase national income and increase the level of community prosperity (Wahyuni, Sukarsa, \& Yuliarmi, 2014). Investment has a crucial role in creating capability and enlarging the supply of products, and investment also has a vital role in the pattern of regional development in developing sectors that are in specific regions to affect regional inequality, especially that private investment is often only concentrated in a particular area only. This is related to their assessment of areas that have promising potential as a place to invest (Adipuryanti, 2015). Based on the description, the first hypothesis can be prepared as follows:

$H_{1}$ : Private investment has a positive effect on the inequality of economic development in district/city regions in the Ex Residency area of Kedu.

Labor is one of the critical development capital besides investment. With a large enough population and followed by a high level of education and useful skills will be able to drive the rate of economic growth because the large population of productive age will be able to increase the number of the available labor force and ultimately will be able to increase output production in an area. The size of the workforce that is large enough and followed by a high level of education and useful skills will be able to drive the pace of economic development which will eventually be able to reduce the inequality. On the other hand, with a large workforce also requiring suitable employment, not to increase the workforce is not matched by the opening of new jobs. This will create unemployment and have an impact on increasing inequality between regions (Habibi, 2016). Based on the description, the first hypothesis can be prepared as follows:

$\mathrm{H}_{2}$ : The workforce has a positive effect on the inequality of economic development in the regencies/cities in the Ex-Residency area of Kedu.

One way to support an increase in regional economic growth is to increase capital expenditure which is one of the sources is from DAK. DAK is a transfer fund from the central government to the regional government that is used to run the construction of infrastructure and public facilities in the district/city. DAK is intended to help finance special activities in certain areas which are regional affairs and following national priorities. DAK is entirely used for capital expenditure to increase public facilities. In other words, no DAK section is used for operational development costs such as official travel costs and so on. Therefore, the demands to change the spending structure become stronger, 
especially in regions that experience low fiscal capacity (Halim, 2013). Through infrastructure development, it is hoped that it will be able to increase the productivity of the community and provide an effect on the level of community welfare which results in a decrease in regional inequality (T \& Purbadharmanja, 2017). Based on the description, the first hypothesis can be prepared as follows:

$H_{3}$ : DAK hurts the inequality of economic development in district/city regions in the Ex Residency area of Kedu.

\section{RESEARCH METHOD}

This study analyzes inequality in economic development between regions. The data used is time series data for ten years, 2007-2016 and cross-section data from 6 districts/cities from the Kedu Residency in Central Java Province. Data sources used are secondary data published by relevant agencies, journals, and other appropriate study materials. This study uses panel data regression analysis. The data needed includes GDP at constant prices, GDP per capita at constant prices, population, the population of Central Java, district private investment, district labor force, and district DAK. The data will be processed using panel data regression analysis to find out the variables that influence development inequality.

\section{RESULT AND DISCUSSION}

\section{Analysis of Data}

The results of the study using multiple linear regression analysis using the Fixed Effect method approach produced the following equation:

Table 2. Panel Data Regression Test Results

\begin{tabular}{|c|c|c|c|c|}
\hline \multicolumn{2}{|l|}{ Variable } & Coefficient & $\mathrm{T}$ & A \\
\hline \multicolumn{2}{|l|}{ Constant } & 0,623236 & 0,901821 & 0,3714 \\
\hline \multicolumn{2}{|c|}{ Private Investment } & $-2,33 E-10$ & $-0,783873$ & 0,4367 \\
\hline \multicolumn{2}{|c|}{ Workforce } & $8,26 \mathrm{E}-06$ & 5,303782 & 0,0000 \\
\hline \multicolumn{2}{|c|}{ Special Allocation Fund } & $-1,12 \mathrm{E}-08$ & $-1,122901$ & 0,2667 \\
\hline $\mathrm{N}$ & $: 60$ & $\mathrm{R}$ & & \\
\hline $\mathrm{F}_{\text {statistik }}$ & : 10,84273 & & R Square & \\
\hline Probability & $: 0,000$ & & & \\
\hline
\end{tabular}

F statistic value of 10.84 which is greater than Ftable of 2.78 and Probability value of 0.00 which is smaller than the alpha value of 0.05 . So it can be concluded that private investment, labor force, and DAK variables have a simultaneous effect on the positive effect on economic development inequality in the six regencies/cities of the former Kedu residency or can be written in the following equation:

$$
\mathrm{KP}_{\mathrm{it}}=0.62-2.33 \mathrm{IS}_{\mathrm{it}}+8.2 \mathrm{AK}_{\mathrm{it}}-1.12 \mathrm{DAK}_{\mathrm{it}}
$$

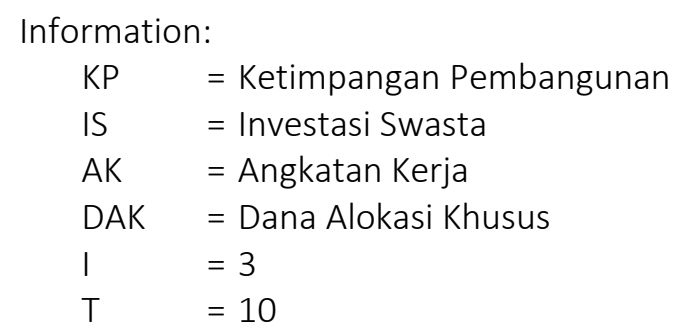




\section{The Influence of Private Investment on Economic Development Inequality in Ex-Districts/Cities of Kedu Residency}

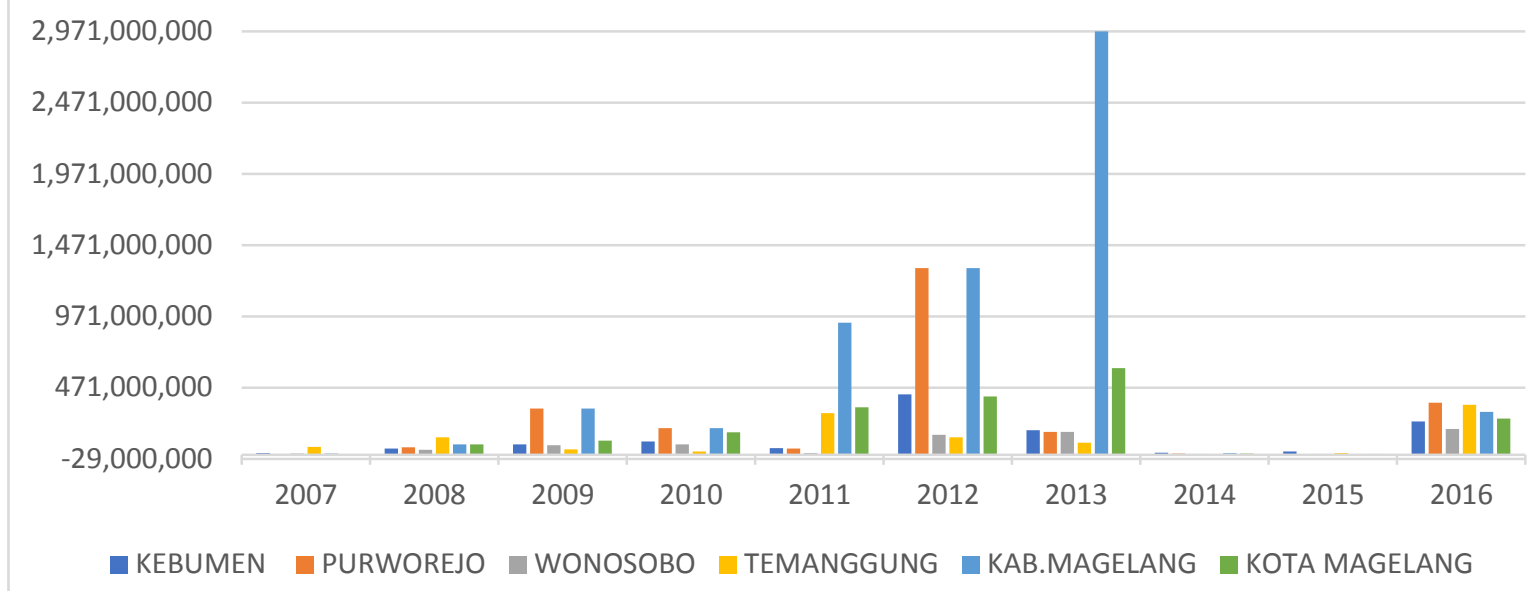

Figure 3. Private Investment in 6 Regencies/Cities in Ex-Kedu Residency

Source: RKPD 6 Districts/Cities of Ex-Kedu Residency 2007-2016

Figure 3 illustrates that private investment tends to fluctuate, and there is a difference in the amount of private investment from year to year in each region. During the study period, in 20072016 it was known that the highest investment made by the private sector was in Magelang regency in 2013, amounting to Rp.2,970,000,000. While the lowest investment is Purworejo regency in 2015 in 2015 amounting to Rp.4,000,000. Differences in private investment in the districts/cities of the former Kedu residency can occur because each region has different potential and resources, so it has a different appeal for investors.

Based on the results of the panel data regression analysis test, the tcount of private investment is smaller than $t$ table, which is $-0.778<2,000$, with a probability value of 0.43 greater than 0.05 or $0.436>0.05$. These values indicate that private investment does not affect the imbalance of economic development.

Private investment is not a factor that determines the size of the inequality of economic development in the territory of the former residence of Kedu. The districts/cities with large and small private investments have relatively the same per capita income. It can also show that the magnitude of private investment in one of the regencies/cities of the former Kedu residency does not necessarily increase per capita income drastically so that it does not have an impact on economic development inequality.

Private investment does not affect the imbalance of economic development because investment creates local companies that can absorb labor in the local area and other areas around it. Therefore investment in an area is not only enjoyed or impacted on the area but also affects other areas that are close together, for example, the business carried out by investors uses not only local labor but also uses other regional workers nearby. Besides, production materials are not only supplied by the local area but also supplied by other regions.

This causes private investment in an area to increase not only the income of the local community but also other nearby areas. Investment activities enable a society to increase economic activities continuously and employment opportunities, increase national income and increase the level of prosperity of the community. Means that private investment in an area creates jobs for the workforce who are not working and are looking for work, and the workforce earns income. So that this private investment affects the income distribution of the population.

In addition to the above possibilities, private investment in an area needs lag time, meaning that the impact can only be felt after the next few years and even then if the investment is sustainable. It does not rule out the possibility that developing businesses recruit workers from other 
surrounding areas and supply materials from other regions so that economic activities also reach outside the region as well as their income. In some cases, private investment means investments made by upper-level residents who have a high share of income, and they tend to prefer to invest in money markets such as portfolio investments as their income media (Nau, 2013).

The Influence of the Working Force on the Inequality of the Development of Ex-District / City Economies in Kedu Residency

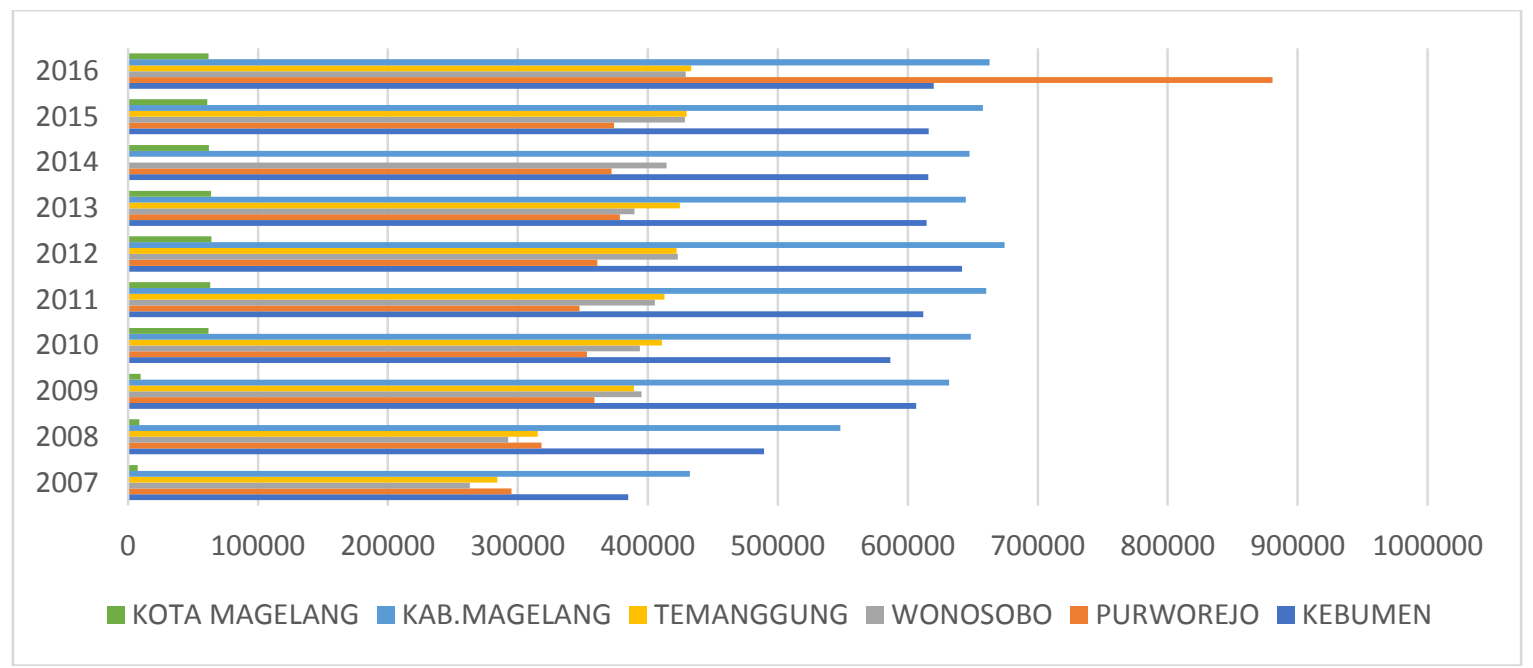

Figure 4. Work Force of 6 Regencies/Cities Se Ex-Kedu Residency 2007-2016

Source: Central Java in Figures 2008-2017, Processed 2018

Figure 4 above illustrates that the number of years tends to fluctuate. Based on the picture above, it is known that Magelang and Kebumen regencies in each year have the most workforce compared to other regions. This indicates that in the two regencies there are residents of working age who work, or have jobs but temporarily do not work, and who are looking for jobs with high numbers. If the workforce is temporarily not working and looking for a large number of jobs, then this certainly causes the low per capita income of the population which can have an impact on the low GRDP of the area.

The labor force $t$ value is 5.303 greater than $t$ table $(2,000)$ or $5.303>2,000$, with a probability value of 0.000 less than 0.05 or $0.000<0.05$. These values can be interpreted that the appointment of work has a significant positive effect on economic development inequality.

The results of the analysis show that the workforce has a positive effect on the inequality of economic development in the district/city of the former Kedu residency of Central Java Province. These results indicate that the workforce is one of the factors that can determine the size of the inequality of economic development. The higher the difference in the labor force, the higher the imbalance of economic development, and conversely the smaller the difference in the labor force, the higher the inequality of economic development in a region. This can occur because the amount of the workforce is a potential input that can be used as a factor of production to improve the production of a company household. The more the workforce, the more workers can be used in economic development activities in an area. Thus the more significant the amount of labor force in an area, the higher the level of economic development in the area, and conversely the smaller the labor force, the lower the level of economic development in the area. This condition has an impact on the widening inequality of economic development between regions in an area with a large number of labor force differences

The results of this study have empirically proven that the workforce has a positive effect on the inequality of district/city economic development former Kedu residency of Central Java Province. The more workforce in an area works, the more residents have income, so that the per capita income of the population is high and in the end, the regional GRDP is also high. So on the contrary, the less 
labor force does not work, the less population has income, so the per capita income of the population is low, and in the end, the regional GDP is also low. Therefore, a significant difference in the number of workforce in each region will affect the difference in population income of each region which is also significant, resulting in significant economic development imbalances between one region and another.

The increase in the number of workforces balanced by new employment opportunities can reduce inequality. This is because the absorption of the workforce will increase people's income. With a large population, mainly dominated by those of productive age like Indonesia today, the workforce can have a significant positive effect on economic development inequality (Barika, 2012). This strengthens the research conducted by Rosmeli (Rosmeli, 2015) that inequality can work in line with the ever increasing number of the workforce so that it needs to be balanced with the opening of new jobs and creative debriefing such as entrepreneurship training. The availability of abundant labor force figures will help in the development process, but if it is not empowered, it will increase the development burden and increase unemployment and exacerbate the inequality rate (Adipuryanti, 2015; Habibi, 2016). The Influence of Special Allocation Funds (SAF) on the Inequality of Economic Development of Ex-
Districts/Cities of Kedu Residency

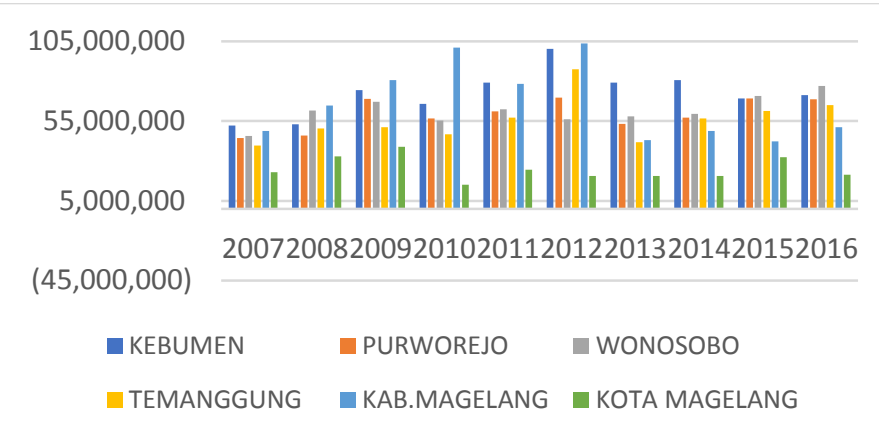

Figure 5. DAK of 6 Districts/Cities of Ex-Kedu Residency in 2007-2016 Source: Director General of Regional Government Financial Balance 2007-2016

Figure 5. above illustrates the DAK situation of each region from year to year tends to fluctuate. During the study period, from 2007 to 2016 it was found that the districts of Kebumen and Magelang regency in 2012 received the largest DAK allocation compared to other regions. This reflects that Kebumen district and Magelang regency in that year had development activities in the form of improving regional infrastructure and facilities that became national priorities, thus obtaining large DAK. Whereas the regions that obtained the smallest DAK allocation during the study period from 2007-2016 were the city of Magelang. This is possible because the development activities in the city of Magelang are sufficiently funded from the APBD.

The titungDAK value is -1.122 greater than -table $-2,000$ with a probability value of 0.26 more significant than the alpha value of 0.05 . This illustrates that DAK does not significantly influence the economic development inequality of a region. The size of the DAK allocation does not cause the size of the economic development gap to be small, because regions that have large DAK allocations have relatively the same level of economic development. This can occur because the Special Allocation Fund provided by the central government in the form of DAK can encourage economic movement through the absorption of labor and capital goods in the field of social infrastructure development (health, education, economy, and public facilities) which are budgeted in development spending in an area. Public facilities in the fields of health, education, economy and public/public facilities such as transportation networks, electricity networks, clean water in all regions are to support the smooth social activities and economic activities of the community. So that DAK becomes increasingly essential for regional development (T \& Purbadharmanja, 2017). 
All regencies/cities in the former Kedu residency obtain DAK so that the state of infrastructure or infrastructure development in the fields of health, education, economy, and other public facilities is also available in the six districts/cities. This situation has resulted in a relatively steady increase in economic development in districts/cities in the former Kedu residency, so that there is relatively no significant economic development imbalance in the region. This is following the aim of giving DAK to the regional government, namely to reduce the development gap especially to fulfill community services between one region to another. Improving infrastructure will increase the productivity of the community which means it can reduce the number of inequality between regions which leads to public welfare (T \& Purbadharmanja, 2017).

Therefore DAK is essential in increasing the capacity of regional government capital expenditure. The trend that continues to increase from year to year is expected to encourage local governments to improve economic development in their regions through the allocation of capital expenditures. Therefore is automatically oriented to the economic development of the community because it is used to build infrastructure and public facilities.

The results of this study indicate that the goal of DAK to reduce the development gap is not achieved. This can happen because the infrastructure does not necessarily grow output, for example, the education infrastructure needs lag time to reap the rewards, health infrastructure and the economy as well as the lag time to be able to reap the rewards. The DAK allocated for a certain period to finance development that is completed at the same time, cannot be directly utilized at that time, let alone directly affecting the increase in income of a region. The infrastructure and infrastructure can only be enjoyed in the following years may be over the next few years.

\section{CONCLUSION}

Based on the results of research and analysis carried out by researchers, some conclusions are obtained, as follows:

(1) Private investment does not affect the inequality of district/city economic development, the former Kedu residency of Central Java Province in 2007-2016.

(2) The workforce has a positive effect on the inequality of district/city economic development, ex-Kedu residency in Central Java Province in 2007-2016.

(3) DAK does not affect the inequality of district/city economic development, former residency of Kedu, Central Java Province in 2007-2016.

\section{Suggestion}

Based on many conclusions from the results of the research and analysis above, the researcher provides several inputs that can be used as recommendations for relevant parties, namely:

(1) The regencies/cities government of the former Kedu residency of Central Java Province should make an effort to increase private investment by facilitating licensing for investors to invest. With private investment can grow employment and employment opportunities, so that residents get high income which in turn can increase income per capita of the population and minimize the imbalance of economic development between regions.

(2) It is expected that in the future the district/city government of the former Kedu residency will pay more attention to sectors that increase the absorption of the workforce in various jobs so that the per capita income of the community increases.

(3) In the distribution of DAK funds, equality is expected so that all regions can enjoy infrastructure facilities, especially for poor regions related to infrastructure facilities.

\section{REFERENCES}

Adipuryanti, N. P. (2015). Analisis Pengaruh Jumlah Penduduk Yang Bekerja dan Investasi Terhadap Ketimpangan Distribusi Pendapatan Melalui Pertumbuhan Ekonomi Kabupaten/Kota di Provinsi Bali. Piramida, 11(1), 20-28.

Barika. (2012). Analisis Ketimpangan Pembangunan Wilayah Kabupaten/KotaDi Provinsi Bengkulu Tahun 2005 - 2009. Jurnal Ekonomi Dan Perencanaan Pembangunan, 4(3), 1-16. 
Ebong, F., Ogwumike, F., Udongwo, U., \& Ayodele, O. (2016). Impact of Government Expenditure on Economic Growth in Nigeria: A Disaggregated Analysis. Asian Journal of Economics and Empirical Research, 3(1), 113-121.

Gasparini, L., Cruces, G., \& Tornarolli, L. (2011). Recent Trends inIncome Inequality in Latin America. Economia, 11(2), 147-201.

Habibi, M. (2016). Pengaruh Tenaga Kerja dan Investasi Swasta Serta Pengeluaran Pemerintah Terhadap Produk Domestik Regional Bruto dan ketimpangan Pembangunan Ekonomi di Provinsi Kalimantan Timur. Jurnal Ilmu Ekonomi Mulawarman, 1(3).

Halim, A. (2013). Manajemen Keuangan Sektor Publik. Jakarta: Salemba Empat.

Lesmann, C. (2012). Regional inequality and decentralization: an empirical analysis. Environment and Planning A: Economy nd Space, 44(6), 1363-1388.

Lessmann, C. (2014). Spatial inequality and development - Is there an inverted-U relationship. Journal of Development Economics, 106(3), 35-51.

Li, Y., \& Wei, Y. H. (2010). The spatial-temporal hierarchy of regional inequality of China. Applied Geography, 30(3), 303-316.

Mopangga, H. (2011). Ketimpangan Pembangunan dan Pertumbuhan Ekonomi di Provinsi Gorontalo. Jurnal Trikonomika, 40(1), 40-51.

Nurhuda, R., Muluk, M. R., \& Prasetyo, W. Y. (2013). Analisis Ketimpangan Pembangunan (Kasus di Provinsi Jawa Timur Tahun 2005-2011). Jurnal Administrasi Publik, 1(4), 110-119.

Reardon, S. F., \& Bischoff, K. (2011). Income Inequality and Income Segregation. American Journal of Sociology, 116(4), 1092-1153.

Rosmeli. (2015). Dampak Investasi dan Tenaga Kerja Terhadap Ketimpangan Pembangunan Kawasan Timur Indonesia. Jurnal Paradigma Ekonomika, 10(2), 362-369.

Simiyu, R. S., Mweru, J. N., \& Omete, F. I. (2014). The Effect of Devolved Funding On Socio-Economic Welfare of Kenya: A Case Constituency Development Fund in Kimilili (Kenya). Journal of Accounting Auditing and Faineance Research, 2(7), 31-51.

Sjafrizal. (2012). Ekonomi Wilayah dan Perkotaan. Jakarta: Raja Grafindo Persada.

T, D. P., \& Purbadharmanja, I. B. (2017). Pengaruh IPM, Biaya Infrastruktur, Investasi dan Pertumbuhan Ekonomi Terhadap Ketimpangan distribusi Pendapatan di Kabupaten Bali. EJurnal Ekonomi Pembangunan, 6(2), 255-285.

Wahyuni, I. G., Sukarsa, M., \& Yuliarmi, N. (2014). Pengaruh Pengeluaran Pemerintah dan Investasi Terhadap Pertumbuhan Ekonomi dan Kesenjangan Pendapatan Kabupaten/Kota di Provini Bali. E-Jurnal Ekonomi dan Bisnis, 3(8), 458-477. 